\title{
Commentary
}

\section{Intellectual and Barbarian Figures in Film: The Bear and the Devil}




\section{ABSTRACT \\ The article suggests that cinematic figures can be divided into two basic groups - barbarian and intellectual. The definition is based on the level of the figures' intelligibility in the works of Jean-Luc Godard and Andrei Tarkovsky. As Claude Lévi-Strauss' myth analysis shows, there are structural similarities between cinematic figures and myths, the article searches for a closer, more site-specific link, engaging fairy tales, i.e. local myths, as a more efficient way of observing the distinctive features of the figures in specific regions.}

\section{INTRODUCTION}

This article focuses on the behaviour of intellectual and barbarian figures in film and their relationships with fairy tales. Several studies refer to the close connections between mythology and cinema - from the archetypal influences on art as such, from the deification of the star system (Eliade [1963] 1998, Morin [1956] 2013) to the profanation of mythology on the screen (Biró 1982), and the structural coherences between film images and visualised myths (Keevallik 2012).

As Claude Lévi-Strauss' myth analysis proves (Lévi-Strauss 1963), the structure of a myth can easily be projected onto the structure of a cinematic figure - both tend, in one way or the other, to reunite the two contradictory extremes of existence.

Setting out to compare the figurative approaches in the film language of different cultures, fairy tales prove to be a better basis for comparison than universal myths. And when it comes to site specificity, a fairy tale - a domesticated myth - provides a closer link between myth and local cinematic expression. Investigating the differences in the use of figurative visual language in French and Russian cinema, I will rely on the works of Jean-Luc Godard and Andrei Tarkovsky - the two great clichés whose influence on the figurative expression trends of the two cultures is still quite obvious. I will explore the extent to which the particularities of cinematic figures are related to local fairy tales.

The distinction between barbarian and intellectual figures - a further elaboration of the 'barbarian metaphor' coined by Yvette Biró (1982) - can be observed in the films of Tarkovsky and Godard. All the good figures are basically wild intruders, their main impact on the spectator is non-rational they work on a sensory, intuitive or affective level. But there are also some that have an idea that can be digested by the mind. The clarity or the blurred nature of this rational ingredient is what constitutes the difference between 'barbarians' and 'intellectuals'. As the nature of Tarkovsky's figures is clearly more savage and Godard's figures rely more on our intellect, the question is: could Godard's 'learned images' have something to do with Puss in Boots?

\section{THE CINEMATIC FIGURE}

The concept of the cinematic figure in question is rooted mostly in Russian film theory, where it is called an образ - a term that is much clearer than the 'figure' or the 'image' of the Western European discourse. The Russian filmmakers Tarkovsky and Andrei Dobrovolski define the figure as a banal everyday phenomenon that works as 
a cinematic figure due to a new and unexpected context on the screen. A figure is always derived from real life, it is not a fruit of fantasy, says Dobrovolski, who is usually more consistent in his theoretical statements than Tarkovsky. He also claims that it is something that has been noticed only by the film director; and therefore, the director is the first person to think of this image (Dobrovolski 2003). This might seem like an exaggeration, but what cannot be ignored is the figure's freshness, one of its essential qualities.

It is important to distinguish figures from symbols (as conventional signs) and from dead metaphors. The rain that is always falling in mediocre films when someone is sad could actually be a figure, as it is affecting the sensory perception of the viewer, and since it is copied from real life, but used as a metaphor for sorrow in film language, it is no longer among the living. A cinematic figure can be compared to a visual metaphor, because it usually includes the word 'like' that is inherent to a metaphor. But a metaphoric bond that is too close usually destroys the figure. Conventional signs are even worse - they do not have much chance of being classified as living figures, for they usually carry a clear rational answer within. If the filmmaker was the first person in the world to come up with the idea of describing poetry as a winged horse, it could, in some specific aesthetics (like Sergei Paradjanov's or Emir Kusturica's, for instance), be considered a figure. For Tarkovsky, this would be too theatrical.

Even if the metaphoric word 'like' exists in the example 'Poetry is like a winged horse, it is clear that the Pegasus on today's screens is a symbol with an immense backstory and it lacks the necessary semantic innocence to create a fresh figure. In any case, to get a clearer idea of the nature of a cinematic figure, it is best to leave fantasy films and science fiction out of this discourse. It is much more interesting to see why an ordinary phenomenon like a raindrop suddenly speaks to us, than to measure the inventiveness of a strange mutant animal.
A pure 'Russian' figure is actually just any image from the street - fantasy and creativity intervene only while smartly displacing an everyday image onto the screen. A visual symbol, on the other hand, is a construction, be it religious, social or cultural one. It should be stressed that this opposition operates on a purely visual level and deep-rooted cultural symbols are treated on an equal basis, for instance, with contemporary logotypes. In this exclusively visual playground innocent objects are easily contaminated by their context. A simple apple, as soon as it is linked to the slightest idea of temptation, becomes a Christian marionette. The same happens to a seashell accompanying an oil man's speech. So, if we deal with a symbol, even if it seems like a simple object at first sight, its relationship to the signified can be rationally traced. The viewer uses his brain to 'read' a symbol, while the figure is 'readable' through a sensory experience - it is essentially irrational, illogical, its relationships to the signified are indirect. Even the intellectual figure initially influences us on the non-rational level; its meaning reveals itself later, and, in fact, only if we look for an answer. We could say that a figure does contain a metaphoric bond, but in its best form, this bond is stretched out so far that reason can no longer link the opposite ends. When it comes to the winged horse, the answer is there before we even start to feel it - we immediately 'know' that this creature means poetry, and we do not have the time to innocently perceive it. So, all knowledge erudition, the experience of having seen too many metaphors - kills the figure before it is born. In this particular situation, a figure and a symbol stand as far apart from each other as the two worlds of Marcel Proust the one we feel in and the one we speak in.

This kind of a generalised distinction could also be projected onto painting, photography, etc. But within the playful art forms (cinema, theatre and other narrativebased art forms) a figure has an important particularity - it acquires meaning in the context of the story. A simple frame torn out 
of a film is rarely figurative, a good figure usually needs a past and a future, especially if we speak about a Tarkovskian figure that is a very typical everyday phenomenon - we would not be able to recognise it if it were just a photo. The same goes for a 'general figure' - one that can pervade the entire film and usually involves the entire visual setup, i.e. the location of the action or a specific reoccurring feature linked thereto. In this case we need time to realise that the image is influencing us in a strange way, we need to have lived with the image for a while to come up with a question like "Why is this house situated in such a deep valley?' or 'Why is this neighbourhood always so muddy, although it doesn't rain?'. We do not always notice the visual 'displacement' straight away.

Before taking the next step, I will briefly outline the other discourses woven around the filmic figure, in order to explain why I have chosen this particular path. Starting with Jean-François Lyotard ([1971] 2011), the French have been fascinated with the idea of a figurative force that lives in all art forms and that almost acts like a war machine against the power of the word (even inside the word, in the case of poetry). Based on cinema theory, Jacques Aumont (1996) has applied this same force to film aesthetics. But he does not really provide a detailed study of the outcomes of this force, but rather deals with the concept of the 'figural' and takes delight in theorising about the power of the image that creates meaning. At the same time, theoreticians who are predominantly from the Englishspeaking world are quite eager to collect large quantities of meaningful images from the screen, mostly calling them metaphors and classifying them into numerous subspecies (Whittock 2009, Clifton 1983, Gerstenkorn 1995). Although dealing with a domain much vaster than that of the figure, these studies have been of great help, because the more poetic or abstract (or borrowed from another domain) the definition is, the more valuable a concrete image is for completing the theory. Even if all metaphors are far from being figures, as mentioned above, the observation of different species has been helpful for defining the borders of the figurative domain. But apart from showing the multitude of meaningful image types (most of the classifications are borrowed directly from linguistics), these collections have little theoretical value for our discourse on the figure. From the French side, the theoretical direction is promising, but it is focused more on philosophising, juggling with great concepts. The idea of connecting the figurative powers to Freudian dream schemes has been very popular in French film theory - from Christian Metz (1977) to Jacques Aumont (1996) and Luc Vanchéri (2011) today, the idea that the essence of the figure resembles the creation of a dream in our brain has been an idea that has been impending for a while. It is true the way that Sigmund Freud's 'dream work' handles the raw material collected during the day, and how 'displacement' operates during the night, looks exactly like Tarkovsky's games with decontextualizing simple images. But when searching for the inner logic of the filmic figure, a comparison with dreams is certainly fascinating, but not efficient. What is needed for the current study is a combination of the Anglo-Saxon and the French approaches - that would bring the French concepts down to earth. This is why I have stayed true to Tarkovsky, who has not said much but whose films speak for him, and also to Dobrovolski. Neither of the two cannot be considered to be just an artist expressing himself. They both have strong theoretical links to Yuri Lotman. The idea of a perfect figure reuniting two opposite phenomena appears in the writings of all three - and it is Lotman's (1990: 44) statement about the possibility of a figure creating new meaning only through juxtaposing 'unjuxtaposable' elements that led me to go looking for help from Lévi-Strauss. We will see why in the next section. And this is not the only thread leading to him. On the other hand, a study of the functioning, the structure and the raison d'être of the playful arts figure with its context-dependency quite naturally leads the research to other narrative-based art forms. And why make 
do with less, why not go straight to the roots of it and see the myth?

\section{THE MYTH AND ITS DESCENDANTS}

The myth, the forefather of all playful arts, becomes a valuable source of references if we manage to look at it as a mere form of theatre (or film). As Johan Huizinga has remarked, the more the literal truth or religious element disappears from a myth, the more the playful element, which has always been inherently part of it, reappears (Huizinga 1955: 130). One must forget about faith and concentrate on suspending disbelief in the good old cinema-goer mode. This 'rundown' myth is a wonderful source of scenic elements - figures, symbols and other more or less talkative images. All the more, what is the work of myth if not to turn existential matters into artistic figures?

What is most helpful is all the work that has been done by anthropologists to discover the inner logic of myths; especially that of the structuralists who have quite unpopularly dissected the beautiful stories with a fork and a knife. For example, the studies of Lévi-Strauss help us realise that there are fascinating similarities between the construction of a myth and the structure of a cinematic figure. Like a myth, a figure is also formed on a contradictory basis or by a collision of two different phenomena. Lévi-Strauss' structural analysis of myth demonstrates how a myth always aims to reunite two contradictory worlds (Lévi-Strauss 1963: 206-231). He disassembles the story, observes the pieces and concludes that all myths are built on pairs of opposites (like life-death, good-bad, etc.) and that the ultimate aim of myth is to bring these opposing elements closer together. He then draws a chart that includes all the elements of the myth arranged so that reading from left to right you get the story, but reading from top to bottom you get the meaning of the myth. He compares myth language to that of music and brings a musical score as an example - reading the latter line by line does not give you any idea of the entire symphony. Myths are quite similar: their real meaning is not apparent from a linear reading or the order of the events. A cinematic figure functions in a similar, indirect way - even if it can be described in words, its inner meaning lies elsewhere. Lévi-Strauss' research, although judged as rigid and indelicate at times, is most welcome for this comparison. For it would not make much sense to compare the figure - a phenomenon that cannot be easily defined - to another, often philosophical, concept of myth, which is mostly already defined in figural language, like Paul Ricœur's 'the misery of philosophy' (Ricœur 1960: 27) or J. F. Bierlein's 'the meaning of life' of (Bierlein 1999: 6). The result would probably be a rather tautological attempt to compare poetry with poetry. If we look at one of Tarkovsky's favourite figures in which an invisible hand spills milk on the ground (this happens in many of his films), would it be promising to compare it to "the meaning of life'? Leaning on a more solid structure, like Lévi-Strauss' model of opposites, seems like a better idea. And if Tarkovsky's milk puddle does not seem to speak about 'life and death' or 'nature and culture' at a first glance, then through some deductions we can easily arrive at words that are just as big (Figures 1 and 2).

The comparison of a myth and a figure is focused exclusively on the visual level. But, as mentioned above, the playful arts' images cannot be handled without their background, their context in the story. So, we can speak about pure images but we cannot ignore their origins; we are dealing with images that constantly carry their documents - birth certificates, etc. - with them. This information is useful for descending Lévi-Strauss' ladder, down to the roots of the image. The main interest in engaging a myth in this study is to follow the genesis of the image from big words, through contradictory elements, to the visual outcome. The image, although just meant to depict an event and thus condemned to fit into one of the boxes in the chart, surprisingly tends to convey the whole 'symphony', thereby revealing the essential meaning of the whole story. 

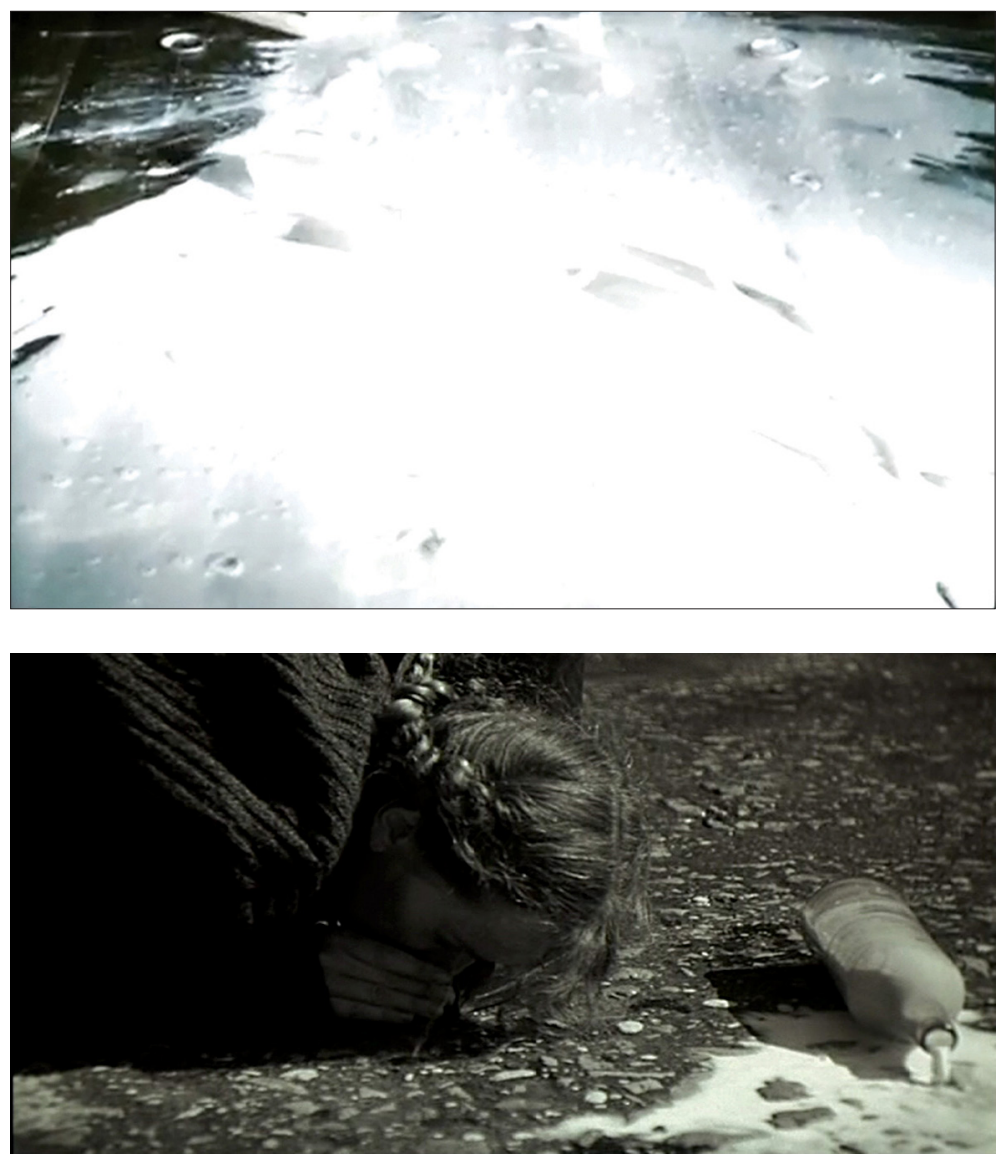

FIGURE 1. Milk anomalies in Tarkovsky's Sacrifice (Offret, Sweden/UK/France, 1986). FIGURE 2. Milk anomalies in Tarkovsky's Nostalghia (Russia/Italy, 1983). 
The results of visualising a classical myth are usually quite theatrical. The aesthetic gap that exists with Tarkovsky's 'simple and banal thing' is immense. One way to bring these two worlds closer together is to study the contemporary myths. For instance, the visual outcomes of the myths of Roland Barthes ([1957] 2012) are almost ready for the screen, they just need to be wittily displaced. Another way is to follow the fairy tales, descendants of the myth that have been simplified and banalised according to local tastes.

There have been many arguments about the filiation of fairy tales - whether they share a common ancestry with myths or not. Bruno Bettelheim, for instance, claims that they are two essentially different things: a fairy tale is always optimistic by nature, whereas a myth would remain pessimistic (Bettelheim 1976: 60-66). He would not describe Little Red Riding Hood as a fairy tale because, in the initial version, the good hunter does not come to cut open the wolf's stomach and save the little girl and she is just eaten up. As a psychologist, Bettelheim is focusing mainly on the child's inner world and he states that it is crucial for a child to know that there will be a happy end. Many people disagree with him. François Flahault draws attention to the fact that fairy tales were never meant merely for children; that their main purpose was always producing pleasure for everybody, no matter what the end would be (Flahault 2001: 5). He also compares fairy tales with pieces of music, although on a different level than Lévi-Strauss - he sees fairy tales as self-contained pieces of music, neither of which necessarily wants to 'say something' (Flahault 2001: 152). This is another idea that has caused conflicts. Jack Zipes sees fairy tales as manuals for good behaviour, each teaching us the specific manners of a specific time and culture (Zipes 2012: 26-29). Every story by Charles Perrault (2009) would be a useful lesson in social issues: Little Red Riding Hood would teach young girls not to follow strangers; Puss in Boots would praise the nobleman's witty assistant who advises his patron while serving him faithfully. The tales of the Brothers Grimm would be deformed in Nazi Germany to match the ruling ideology. Without denying these later modifications, this study remains true to the concept of seeing a fairy tale as a 'miniature myth' (Lévi-Strauss 1983: 130), freed from the sacred. In the same way as Huizinga speaks about the playful element that gains ground as the sacred vanishes, Cristophe Carlier sees the degree of the sacred as a major difference between myths and fairy tales (Carlier 1998: 10-11). A fairy tale could never become a cult object, its sources are in popular superstitions and it has no place in temples or churches, its place is in front of the hearth. Bettelheim remarks that the events in a fairy tale can be supernatural, but never as mystical as those of a myth - basically, it could all happen to your neighbour while taking a walk in the woods. This simplification brings myths down to earth, much closer to the 'plain and banal' matter that forms the perfect figures on the screen. Thus, fairy tales might be the missing link between myths that are spoilt by the sacred, and figures that are made of everyday magic.

An interesting idea that Bettelheim points to is the two-dimensionality of the characters in a fairy tale. If someone is good or bad, it is ultimately and irreversibly so; if someone is beautiful or ugly, there are no 'buts' about it. Vladimir Propp ([1928] 1970) has dissected fairy tales in the same way that Lévi-Strauss has myths, and discovered that the functions and the attributes of fairy tale characters are extremely limited. This flatness clearly reveals the contradictory elements that are hidden somewhat more successfully in myths - after all, aren't fairy tales just filled with Lévi-Strauss' pairs of opposites, walking around with a crooked nose or with a crowned head?

So, even if 19th-century popular opinion considered fairy tales to be narratives ruined by the stupid peasants that retold them so many times that the initial meaning was lost, it was beneficial for this study, because the brave peasants did half the job of bringing myths closer to everyday 
life. What is even more precious is the local specificity that the fairy tales carry, because Perrault's lessons of sociology, for example, help bring us closer to understanding the French way of figurative thinking and their taste in transforming universal myths.

\section{BARBARIAN AND INTELLECTUAL FIGURES}

There is also something else that stands up for the defence of the 'stupid peasants'. The 'savage mind', a term coined by LéviStrauss (1966) for describing the necessary precondition for myth-making, proves to be of utmost importance when creating fresh figures à la Tarkovsky.

The savage mind is opposed to the civilised, systematic mind. The latter studies the universe and draws reasonable, scientific conclusions, while the wild thinker could be described as observing a pile of debris and assembling his world from the pieces found there. This is what LéviStrauss calls bricolage (a DIY way of dealing with the world), the creation of a 'homemade' universe (Lévi-Strauss 1966: 17-33). A bricoleur is a handyman who does not know the names of his tools or other strange objects that he has in the corner of his shed; he has just collected them all his life, because 'one might need them someday'. This is what he builds his worldview from. However, the way he joins the pieces presupposes a certain intellectual activity - he analyses and compares the objects, thus demonstrating a capacity for generalisation. This perfectly matches the activity of a Tarkovskian figure picker who also needs savage magical thinking for intuitively finding images; and some intellectual abilities to be able to displace the thing to the screen. Thus, a filmmaker must first unlearn, be able to look at a pile of bric-a-brac through the eyes of a child, of a primitive man, of a savage thinker. If we look at Eisenstein's 'montage of attractions' (Eisenstein [1925] 1974: 118-130), doesn't it dramatically resemble the worldview of a primitive man where the only link between the pieces forming a kaleidoscopic constellation is their position in the space (Biró 1982: 157)?
Yvette Biró has observed this savage thinking in film classics and has concluded that cinematic thought in its best form is magico-mythical thought that tries to inject a pinch of eternity into the objects extracted from the triviality (Biró 1982: 128). This sounds like Tarkovsky's seemingly lunatic statement that the more a figure represents the typical, the more it is original. The originality of a cinematic figure lies in its typicality (Tarkovski 1981). Biró develops the concept of a 'barbarian metaphor' that attacks the screen with objectivity. Although she is referring to all the cinema's different means of expression, she is also bringing some good examples of visual 'barbarians' that function like figures - for example, Bergman's sweating males and females or Fellini's highway traffic jams (Biró 1982: 158-159). They both strike with objectivity or typicality. For Biró, a metaphor on the screen is not 'a humble servant but a provocative prostitute who sells her body in order to convey a certain idea. It is not a hint, a reminder or a parallel, but a violent intruder, a sensual and shameless reality' (Biró 1982: 157). The violence and impoliteness certainly come from the rude displacement of the typical image into a new context.

All good figures come from a savage realm, but not all of them are as vulgar as that. In their essence and origins, they are all barbarian, but there are some that are somewhat more 'educated'. This does not mean that they would knock on a door before entering the screen, it just means that they are more learned and their weapons are more spiritual. These figures are called 'intellectual figures' and they are distinguished from the real barbarian figures by their ability to read and write, more precisely: their ability to play with words.

In these two large groups of the figure species, the first division (there are several subspecies springing out from these two) can be observed in the examples of Tarkovsky and Godard themselves. It may seem to be a trivial choice but it is quite adequate in the given framework, because Western and Eastern European cinematic figures 
still seem to be rooted in the approaches of these two directors. Of course, Tarkovsky was quite a logical choice, for only his films can help us understand his somewhat vague theoretical statements. The need for Godard inevitably appeared in France, where I went, armed with Tarkovsky's criteria, to look for 'real figures'. While systematically watching a large number of French films, becoming more and more disappointed because the 'real' ones were more than rare, Godard emerged as a force majeure from the bottom waters of French film production. He was the answer, whispering: 'Mind the word!' The long French theatrical tradition is obviously responsible for an excessive love of the word in French culture as a whole, but Godard as the great word ambassador in cinema is a good key to unlock French film figures. His apparition also revealed the fact that both he and Tarkovsky still reign over their territories and have quite strongly influenced the figurative film language of Western and Eastern Europe - another reason for choosing these two as the raw material for this study.

Let's look at some examples. The final image of Stalker (Сталкер, Tarkovsky, Russia, 1979) is the strange taciturn daughter who uses psychokinesis to make the glasses filled with water move and the whole house suddenly starts to shake.

(Figure 3) The noise of a train then subtly joins in. This is quite an impolite figure. There can be no concrete answer to the question 'What does it want to say?' The image strikes us on a non-rational level and the answers - or rather feelings - could vary from A to Z. It is a mute barbarian intruder.

The first example of an intellectual figure comes from Godard's Two or Three Things I Know About Her (2 ou 3 choses que je sais d'elle, France/Italy, 1967). An anonymous gentleman is stirring sugar in his coffee cup and a voice-over is pondering existential issues. (Figures $\mathbf{4}$ and 5) The camera zooms in on the coffee cup from above and during the inner monologue we plunge deeper and deeper into the whirling foam, until the image becomes disconnected from the coffee. In this dreamlike whirlpool, the volutes of foam turn into a flock of unidentified heavenly bodies in outer space that vanish into the black hole in the middle. Although quite wild in the end, this figure is an intellectual one. It makes no sense to discuss the possible answer to 'what it wants to say', because the mysterious whispering voice tells us everything - it is meditating on the impossibility of both rising to the level of being and falling into nothingness. A hole as black as coffee almost acts like an illustration for the text. The same can be said about the focus play - as the talk gets more and more metaphysical, the foam becomes blurrier, but when the voice says 'if we concentrate', it comes back into focus again. It is an impressive figure, but too civilised to be ranked among the real barbarians.

French figures tend to be more talkative, and are often linked to the word, even if they are at odds with the latter. Of course, things are not that black and white. Some intellectual figures have also slipped into Tarkovsky's films. When the emigrant tries very hard to walk across the courtyard with a burning candle, while making efforts to protect the flame from the wind, it is quite clear that he is aiming to preserve a memory or some other ephemeral matter. Things become quite obvious if we put the title Nostalgia (Nostalghia, Russia/ltaly, 1983) under the image. Isn't it strange that the less talking they do in a film, the more important the title becomes? Although there is a barbarian side to this image: why would it all occur in a forlorn pool? The filmic context of the figure tells us this is a tribute to the mad, suicidal friend of the flame keeper. But in fact, the image becomes larger than that. It floats away from its 'explanation'; it starts telling its own story in its own language - and this is one of the basic intrinsic qualities of a good figure.

Tarkovsky's spooky landscapes and weather anomalies - the absurd wetland around the house, the famous milk on the floor, the rain falling inside or the crazy dandelion seed storms in the air - they all have the ability to deviate from the 

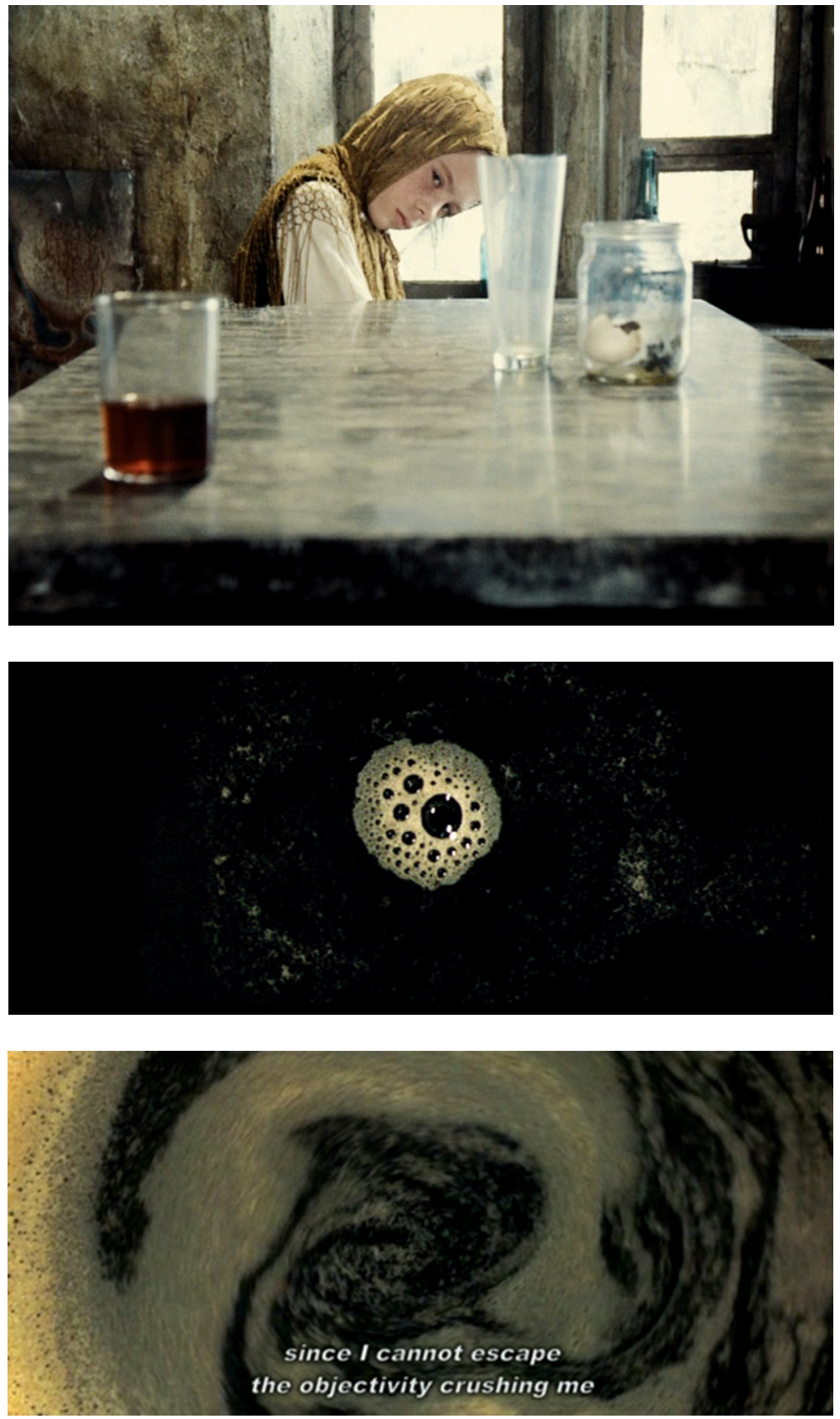

FIGURE 3. Stalker's daughter (Natasha Abramova) using psychokinesis to move the glasses in Tarkovski's Stalker (Сталкер, Russia, 1979).

FIGURE 4-5. Godard's coffee in Two or Three Things I Know About Her ( 2 ou 3 choses que je sais d'elle, France/Italy, 1967). 
storyline; to start telling a new story. These are all perfect barbarians. Like the super shining floors in Sacrifice (Offret, Sweden/ UK/France, 1986) that do the same job as the indoor rain: the reflection doubles the image, 'on earth as it is in heaven'. Is this an answer? There is much room for interpretation in all of these cases.

In the case of Godard, there is not that much room. When a beautiful philosophising girl (Godard's favourite) confesses how one day she felt she was a part of the entire world, the girl's head is at the bottom of the frame and the rest is filled with a huge apartment building. (Figure 6) Since, once again, the image matches the spoken words, it classifies as an intellectual figure. Godard loves playing with words, and especially with visualised words, like book titles, neon ads or posters, that appear in the frame 'by chance'. In Pierrot le fou (France/ Italy, 1965), the fresh lovers steal a car and flee, and their first stop in 'freedom' is at a gas station outside the city, where the word 'Total' decorates most of the frames in the sequence, either in a close-up or in a long shot. (Figures 7 and 8)

As 'Total' happens to be a very wellknown chain of gas stations in France, the realistic provenance of the figure is unquestionable. A 'Total' sign is so typical in the French landscape that one barely pays any attention to it on the screen. Even if reading skills are necessary to unlock this figure, it probably comes from the barbarian camp, because the word does not convey any concrete information - instead of pushing on the rational button, it has a sensory impact on the viewer, like wallpaper. Thus, one can find both kinds of figures in the works of both filmmakers, but in Tarkovsky's world the barbarian ones prevail, while the intellectual figures rule Godard's world.

If we were to try and define these two types of figures, it could go like that - a barbarian figure is a phenomenon totally independent of the film's narrative context, its existence does not have any rational explanation; an intellectual figure is either slightly connected to the film's narrative context or can somehow be read with the intellect.
Dobrovolski (2003) states that the figure has a dual nature, it contains:

- a logical idea - based on the part that can be put in words,

- $\quad$ an emotional feeling - based on the part that is impossible to formulate.

Based on this definition, we can say that in the intellectual figure the former predominates and in the barbarian one, the latter. Although Dobrovolski is too tolerant about letting the reasonable in - 'logics' should not have anything to do with this discourse. Anyway, we can say that the difference between the two types of figures basically lies in the clarity or vagueness of the idea. But both types are still created by good handymen-bricoleurs who have picked up the images from everyday banalities, relying only on their savage minds.

\section{THE BEAR AND THE DEVIL}

If Vladimir Propp says that the bear is cheated in Russian fairy tales and the devil is cheated in Western European fairy tales (Propp [1928] 1970: 12-13), does it not sound like he is talking about barbarian and intellectual figures? Would Tarkovsky still be cheating the bear and Godard the devil?

When Propp points this out, he is actually looking for new ways of classifying fairy tales, in order to get away from 'animal stories' and 'princess stories'. This is an example of the different versions of the same story. The Russian version is about a bear that threatens to eat a farmer, and in order to save his skin, the farmer offers him half his harvest. The bear has to choose whether he wants the tops or the roots, and he ends up taking the tops of the parsnips; the next year when he is wiser he gets the lower parts of the wheat. The French version is exactly the same, except the bear is replaced by the devil. An intriguing coincidence?

Let's look at the imagery of some wellknown fairy tales, starting with cannibals: if Baba-Yaga openly puts the cauldron on fire when she plans to eat her niece, then Bluebeard puts up a smokescreen when 

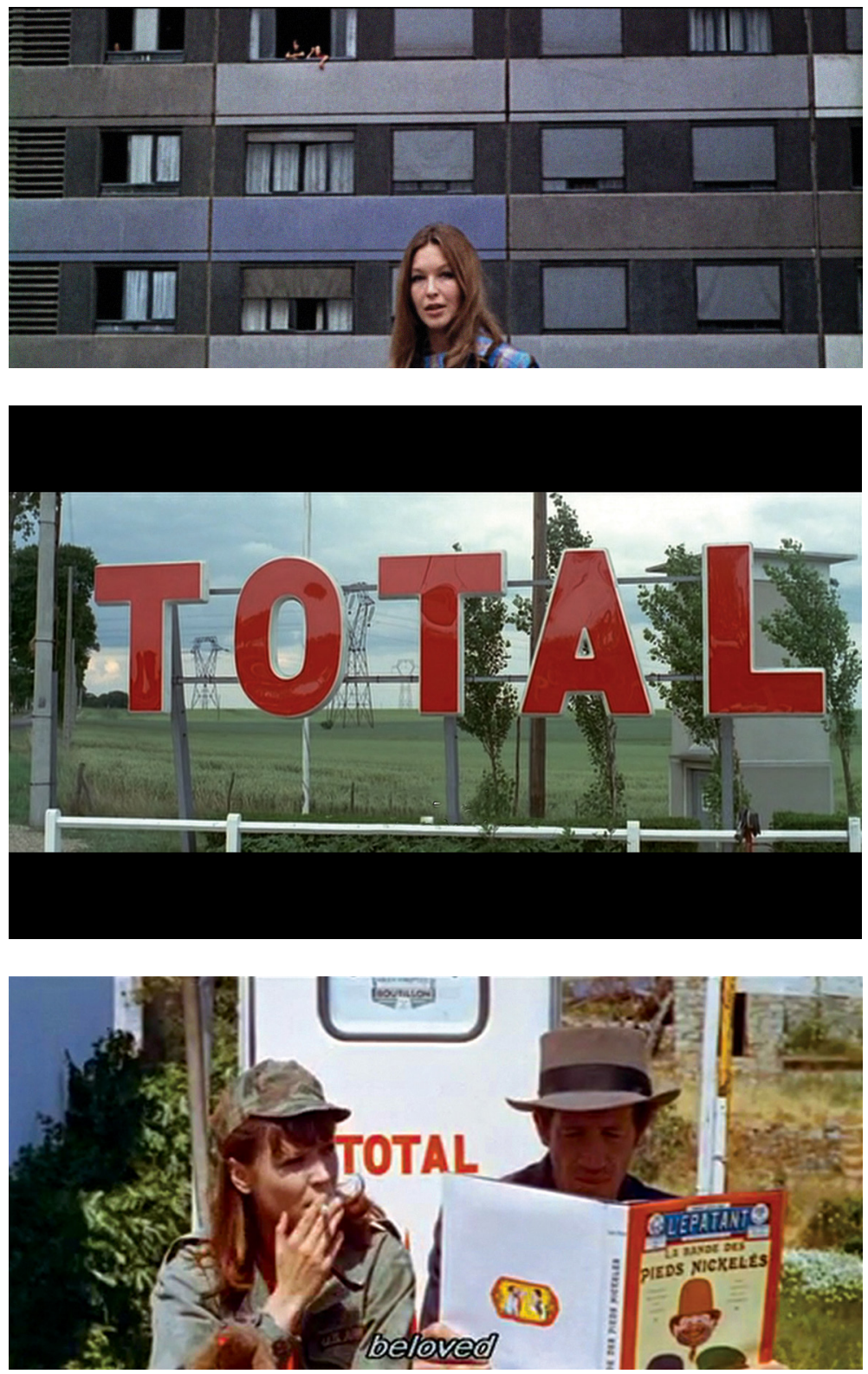

FIGURE 6. Juliette (Marina Vlady) in Godard's Two or Three Things I Know About Her ( 2 ou 3 choses que je sais d'elle, France/Italy, 1967).

FIGURE 7. The Total gas station in Godard's Pierrot le fou (France/Italy, 1965).

FIGURE 8. Marianne (Anna Karina) and Ferdinand alias Pierrot le fou (Jean-Paul Belmondo) in Godard's Pierrot le fou (France/Italy, 1965). 
he secretly devours his wives. If Baba-Yaga is simply hungry, then Bluebeard is a systematic serial killer, and there is a touch of delicate Hitchcock-like horror in the story. Could we say that the Russian tales are wilder?

If in France a beautiful princess is locked up in a tower or put to sleep for a hundred years, then in Russia the annoying character is just stuffed into a barrel and thrown into the sea - and this is what happens with the noble Tsar Saltan (in The Tale of Tsar Saltan, of His Son the Renowned and Mighty Bogatyr Prince Gvidon Saltanovich, and of the Beautiful Princess-Swan [Cказка о иаре Салтане, о сыне его славном и могучем богатыре князе Гвидоне Салтановиче и о прекрасной царевне Лебеди], 1831) by Alexander Pushkin! So, it cannot be argued that the choice of fairy tales is tendentious, and unfairly, only the lower-class popular tales have been chosen from the Russian side.

Many inconvenient characters are stuffed into barrels in Russian tales, among them Emelyan who has made the Tsarevna fall in love with him with the help of the Pike. It is quite a well-known fact that in Russian fairy tales the stupid and the lazy are the luckiest. If Puss in Boots has to start from nothing, and earn the King's sympathy, then neither Ivan the Fool or Emelyan have to make any effort. They end up as beautiful boys, through a simple magic trick, and nobody mentions their silliness anymore. In France, the Bluebird sits under the window of Princess Florine every night, to listen to her intelligent stories, and he understands straight away when the clever princess is replaced by a stupid one. The Russians seem to care less for wisdom, although they have some outstandingly clever characters - mostly women - like Vassilissa or Elena. The lives of Russian men are led by force majeure, the kind possessed by a bear who, without realising his own strength, smashes the entire Terem-Teremok (a small cottage). To be honest, the master of Puss in Boots does not have to make an effort either - it is the cat that does everything for him. But French fairy tales tend to deal a lot with social issues - the cat and his master are typical career-builders. The cat's own interests are at stake and that's why he works for his master. But why should the whole forest work for Ivan? 'Diplomatically correct' activities are much more appreciated in the French tales. Puss in Boots has to take the caught rabbits to the 'right' place, in the sight of the king. And why would he wear boots, after all? All the better climb the social ladder? The French tales also respect hierarchy - disguised or not. It is always a prince that tries to get in contact with the princess, while in Russia a random fool is engaged in the quest for the noble Tsarevna's hand. Cinderella might be a random orphan, but she is exceptionally beautiful and intelligent enough to blend into noble society. Neither Ivan nor Emelyan have the qualities that could serve for career building, they are basically famous because they arouse sympathy.

When it comes to communication, the Russians care less for hierarchies and for social conventions. Luck plays an immense role. Animals are most helpful in this regard - a crab who passes by accidentally will later go to get Vassilissa's dress from underneath a stone at the bottom of the sea; a random wolf offers the hero a handkerchief that can create a burning lake; Masha convinces an apple tree to help her. The relationships are more straightforward and immediate, neither discriminating nor selective. Emotions often interfere - a scary animal you might meet in the forest quite quickly feels sorry for you and helps you.

There is a fair amount of surrealism in Russian tales - the talking Bun (Колобок), for one, should undergo psychoanalysis. It is easy for the Freudians to explain The Beauty and the Beast as the fear of one's own sexuality, or see social lessons in it; like Zipes does, explaining that girls were often supposed to marry older and physically unattractive men and that this tale served as encouragement for them (Zipes 2012: 53). Well, the Russians have a solution - when all the difficulties have been surmounted and everything is fine, except that Emelyan is still ugly, his new wife Maria just asks: 'Emelyan, couldn't you become 
a beautiful boy?' Emelyan then just needs to talk to the Pike and it is arranged - he becomes an irresistibly handsome man.

Based on these few examples, there is little doubt that the Russian fairy tale figures have an irrational bent, while the French remain more reasonable. If we compare the two mystical birds - the French Bluebird and the Russian Firebird - then the former is just an enchanted prince in love. The latter is mysterious: all we know about it is that every Tsar desperately wants to own it. We also know that its feather might bring bad luck at certain moments, and that at night the bird steals golden apples. Nobody knows why. This character takes us to the realm of shadowy poetry, quite exceptional for a fairy tale - usually the fairy tale characters know what they want and why. Could it be a possible explanation for the Russian cinematic figures' strong inclination toward the barbarian side, where there are no answers? It feels somehow linked to the 'nameless yearning' that the Russians call mocka and the Portuguese saudade, for which a word does not exist in many languages.

Let's take a look at one more fairy tale that exists in different local versions: the Russian The Tale of the Fisherman and the Fish (Сказка о рыбаке и рыбке, 1833) and the French The Ridiculous Wishes (Les Souhaits ridicules, 1697). The Russian version (by Pushkin) speaks about a golden fish that promises to fulfil all the fisherman's wishes if he only lets it return to the water. The fisherman has a bad-tempered wife who becomes so greedy that they lose all the rewards in the end. At first the wife asks for a new bench, then a new house, then a castle, golden dishes, new shiny clothes, servants, etc. Then she thinks that she should be a Tsarevna, after that she also wants to rule all the seas of the world and have the golden fish as her servant. As the number of wishes is unlimited, it goes on until the fish has enough.

The French version (by Perrault) talks about a woodcutter, and instead of the fish, we meet Jupiter himself. The number of wishes is reduced to three (a pedagogical mentality, indeed!). When the woodcutter comes home, he sighs, without thinking, 'I wish there would be some sausage.' A sausage appears and his wife gets furious about having wasted one of the wishes for such a stupid thing. She yells at her husband until he loses his temper and wishes the sausage would grow onto his wife's nose. This, of course, happens. Now the woodcutter calculates that it makes no sense to become a king if your wife has a nose like that. So, instead of asking for gold and diamonds, he wishes for his wife's nose to be normalised with his third wish.

The outstanding fact here is the concern about one's social reputation, about what others might think. The two versions of the same story serve as a perfect example of the differences of attitude in the French and Russian tales. If the Russian wish list exceeds all limits, gets out of control like a force of nature; then the French just end up stuck in a family drama, quarrelling with each other and worrying about social shame. This matches the aforementioned social sensitivity of the French fairy tale characters. It is worth mentioning that relationship dramas and romantic (or nonromantic) comedies constitute a huge part of French film production. Throughout their long theatrical tradition, this appears to be the favourite genre of the French audience. The Russians prefer action films or the other extreme - high-quality artistic films.

If a Tarkovsky film with its barely visible drama and the rain falling indoors might resemble a force of nature, then a Godard movie always conceals an intellectual half-smile; an ironic-comic touch is often included to make the intellectuals giggle. Tarkovsky's milk spreading out on the asphalt could be seen as a natural catastrophe, like the absurd avalanche of the fisherman's wife's wishes; whereas Godard keeps his 'civilised liquid' carefully in a coffee cup and admires the bubbles appearing on its surface. Is coffee not the most social liquid of all? Except for Tarkovsky's forsaken coffee - he would let wild nature directly hit civilisation with heavy rain falling straight 
into the coffee cup and blurring up all boundaries. (Figure 9)

It is possible to think that Godard's coffee drinker must stare at his cup because the beautiful Marina Vlady is looking at him provocatively from the table next to him. Male-female relations sneak in like the sausage drama in the woodcutters' house. The fisherman's case has nothing to do with the family or other social constructions, the issue is more animalistic and the characters flattened to the extreme - the wife is immutably greedy and the man a catastrophic loser, nothing is going on between them, the situation is fatal. The French story is more realistic; both characters have average tempers. The mutations of this story provide an excellent example of the regional particularities in the taste for fairy tales as well as the preferences for visual figures.

\section{CONCLUSION: THE BEAR ERROR}

An exceptional phenomenon among the army of flat fairy tale characters is the Bear error. The Bear of Russian fairy tales is an interesting character. He is very human most of the time - as soon as you beg him, he gives up his plan of eating you. The Three Little Bears become sad when they see that someone has eaten their porridge, but they do not plan any revenge. As for the Bear cheated by the farmer, we read: "The Bear no longer wanted to go on cultivating crops with the farmer.' Although he would have every reason to eat the man. Another Bear just wants to stay close to Masha, even if she swindles him. The Bear's goals are quite vague: in principle, he would like to eat everybody, but at the same time, he would like to protect them. (Figure 10)

This is a 3D character; it would be unjust to call him flat. Compared to the Bear, the Western Big Bad Wolf is an extremely clear-cut character: he would like to eat the small spoilt girl with the red hood, and he does it. Logic is on the Western side again. The Bear carries all the possible contradictions within himself, recalling Lévi-Strauss' pairs of opposites as well as Tarkovsky's idea of a perfect figure as a reflection of the entire world. The Bear is good and bad, sweet and terrifying, enemy and friend. Could this dim-witted, emotional animal be responsible for the irrationality of Russian figures?

The Devil of the Western world is not bright either. But he never gets emotional, he is programmed to tease people and he does not veer from this track. He is a rather flat creature. What's more - he is a human invention. Cheating him involves a double intellectual game - first you invent the enemy, then you fight him. Like Jupiter in the woodcutter's tale - you first invent him and then start asking him for favours. On the Russian ground, things are simple; the scale is one to one. You are just confronted directly by nature itself. In Lévi-Strauss' terms, there is a raw vision and a cooked vision. The cooked or the civilised being obviously the one where the animals wear boots!

If Godard says that cinema is 'a thought that forms a form that thinks' (Godard 1998:97-101), then Tarkovsky does not want the image to think, he just wants it to be there and to reflect. He speaks about an absolute image that always surpasses an idea, because an idea (or a thought) is limited: "In a word, the image is not a certain meaning, expressed by the director, but an entire world reflected as a drop of water. Only in a drop of water!' (Tarkovsky 1989: 110).

This is the magical formula that unites Tarkovsky's milk and Godard's coffee - the 'entire world' fits into both of them. In less poetic words, they both contain two extreme opposites of what can be considered the great axes of our understanding of the world; and strangely these two 'ends' create a mirage as if all that existed between them was also present in that image. Both of these two figures manage to contain it all, in a similar manner, they only differ in their degree of savagery - and it is not impossible that they have been somewhat dependent on the behavioural models of the favourite stories of their geographical areas. Stalker's house trembling like a train is as mad as Terem-Teremok, stuffed with too 

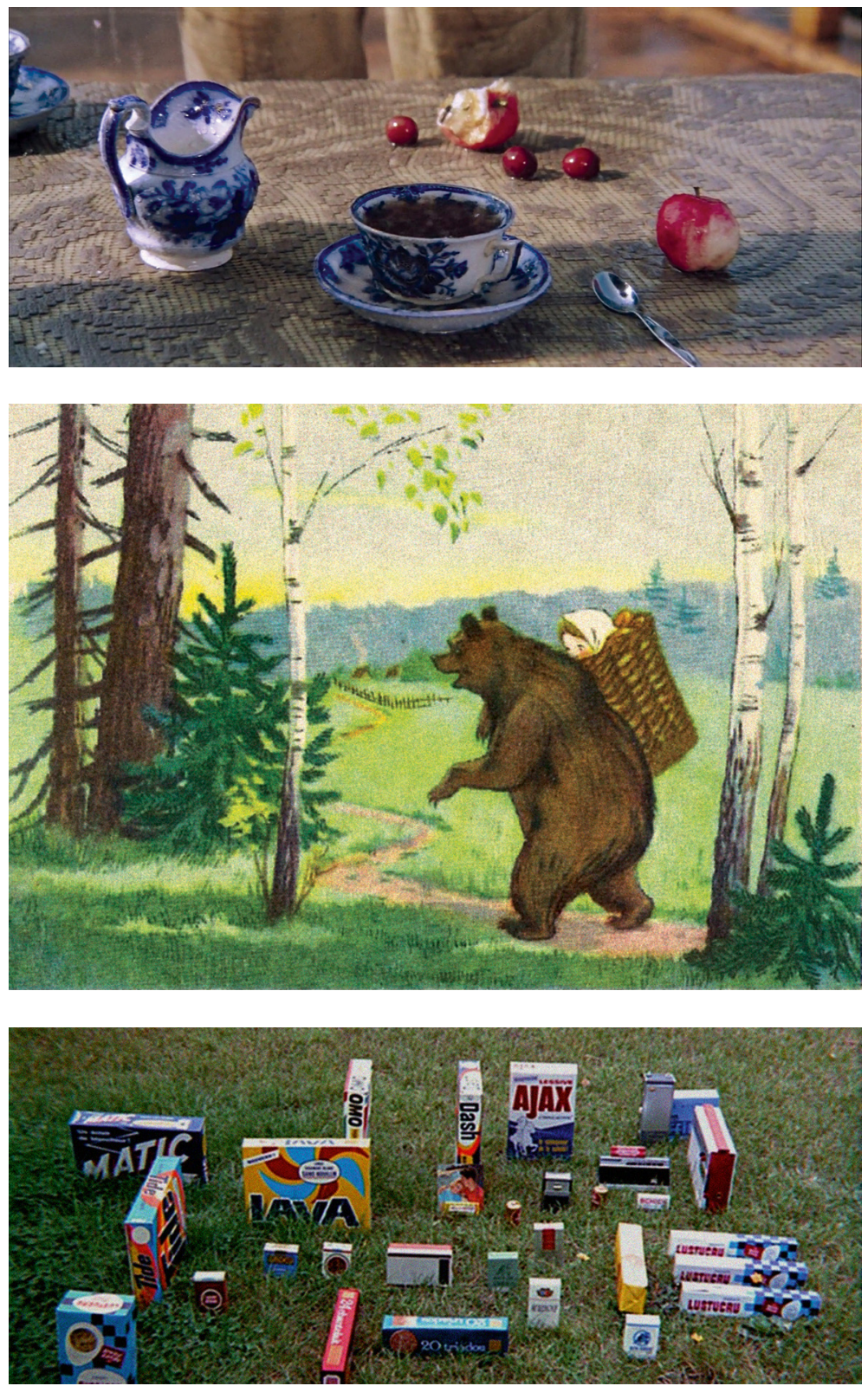

FIGURE 9. Tarkovski's coffee in Solaris (Солярис, Russia, 1972). FIGURE 10. T. Sazonova's 1950s illustration for the Russian folk tale Masha and the Bear (Мама и медведь).

FIGURE 11. The Finale Grande of Godard's Two or Three Things I Know About Her ( 2 ou 3 choses que je sais d'elle, France/Italy, 1967). 
many animals or the wild Bun rolling around the forest. On the other hand, the packages of laundry detergent in the grass in the final scene of Two or Three Things I Know About Her (Figure 11) seem to be placed there by Puss in Boots, carefully laid out, side by side, for the King to notice them.

\section{REFERENCES}

Aumont, Jacques 1996. À Quoi pensent les films. Paris: Nouvelles Editions Séguier.

Barthes, Roland [1957] 2012. Mythologies. Trans. Richard Howard, Annette Lavers. New York: Hill and Wang. Bettelheim, Bruno 1976. Psychanalyse des contes de fées. Paris: Pocket, Robert Laffont.

Bierlein, J. F. 1999. Living Myths: How Myth Gives Meaning to Human Experience. New York: Ballantine Wellspring.

Biró, Yvette 1982. Mythologie profane. Cinéma et pensée sauvage. Trans. Georges Aranyossy, Georges Kassai.

Paris: Lherminier.

Carlier, Cristophe 1998. La clef des contes. Paris:

Ellipses.

Clifton, N. Roy 1983. The Figure in Film. London, Toronto: Associated University Press.

Dobrovolski, Andrei 2003. Master class. Allfilm. Tallinn.

Eisenstein, Sergei [1925] 1974. 'Le Montage des attractions au cinéma'. - Au-delà des étoiles: OEuvres 1. Trans. Andrée Robel. Paris: Cahiers du cinéma, 127-143.

Eliade, Mircéa [1963] 1998. Aspects du mythe. Paris: Gallimard.

Flahault, François 2001. La pensée des contes. Paris: Anthropos (Economica).

Gerstenkorn, Jacques 1995. La Métaphore au cinéma. Les Figures d'analogies dans les films de fiction. Paris: Méridiens Klincksieck.

Godard, Jean-Luc 1998. Histoire(s) du cinema 3: La Monnaie de l'absolu. Une vague nouvelle. Paris: Gallimard-Gaumont.

Huizinga, Johan 1955. Homo Ludens: A Study of the Play-element in Culture. Boston: Beacon Press. Keevallik, Liina 2012. La Figure visuelle des arts joués. Ses rapports au mythe. Une recherche sur la création de figures cinématographiques par des moyens mythologiques. PhD thesis. Université Paris 8. Lévi-Strauss, Claude 1963. Structural Anthropology. Trans. Claire Jacobson, Brooke Grundfest Schoepf. New York: Basic Books.

Lévi-Strauss, Claude 1966. The Savage Mind. Trans. George Weidenfeld, Nicolson Ltd. Chicago: University of Chicago Press.

Lévi-Strauss, Claude 1983. Structural Anthropology 2. Trans. Monique Layton. Chicago: University of Chicago Press.

Lotman, Yuri M. 1990. Universe of the Mind: A Semiotic Theory of Culture. Trans. Ann Shukman. London, New York: I.B. Tauris.

Lyotard, Jean-François [1971] 2011. Discourse, Figure. Trans. Antony Hudek, Mary Lydon. Minneapolis: University of Minnesota Press.

Metz, Christian 1977. The Imaginary Signifier: Psychoanalysis and the Cinema. Trans. Celia Britton, Annwyl Williams, Ben Brewster, Alfred Guzzetti. Bloomington, Indianapolis: Indiana University Press. Morin, Edgar [1956] 2013. Le Cinéma ou l'homme imaginaire. Essai sur l'anthropologie. Paris: Les Éditions de Minuit.

Perrault, Charles 2009. The Complete Fairy Tales. Trans. Christopher Betts. Oxford: Oxford University Press.

Propp, Vladimir [1928] 1970. Morphologie du conte. Trans. Marguerite Derrida, Tzvetan Todorov, Claude Kahn. Paris: Éditions du Seuil.

Ricœur, Paul 1960. Philosophie de la volonté II: Finitude et culpabilité. Paris: Aubier.

Tarkovski, Andrei 1981. 'De la figure cinématographique'. - Positif 249, 29-38.

Tarkovsky, Andrei 1989. Sculpting in Time: Reflections on the Cinema. Trans. Kitty Hunter-Blair. London: Faber \& Faber.

Vanchéri, Luc 2011. Les Pensées figurales de l'image.

Paris: Armand Colin.

Whittock, Trevor 2009. Metaphor and Film. Cambridge: Cambridge University Press.

Zipes, Jack 2012. Fairy Tales and the Art of Subversion. New York: Routledge. 